\title{
KARAKTERISTIK BUTIR SOAL TRY OUT TEORI KEJURUAN AKUNTANSI SMK BERDASARKAN TEORI TES KLASIK DAN TEORI RESPONS BUTIR
}

\section{CHARACTERISTICS OF ACCOUNTING VOCATIONAL THEORY TRIAL TEST FOR VOCATIONAL HIGH SCHOOLS BASED ON THE CLASSICAL TEST THEORY AND ITEM RESPONSE THEORY}

\author{
Oleh: \\ Dian Normalitasari Purnama \\ Universitas Negeri Yogyakarta \\ dianpurnama@uny.ac.id
}

Fitri Alfarisa

Universitas Pendidikan Indonesia

alfarisa@upi.edu

\begin{abstract}
Abstrak
Penelitian ini bertujuan untuk mengetahui karakteristik butir soal tes Try Out Teori Kejuruan Akuntansi. Karakteristik butir soal yang dilihat meliputi karakteristik butir kualitatif yaitu aspek materi, konstruksi, bahasa dan secara karakteristik butir kuantitatif yaitu tingkat kesukaran. Penelitian ini merupakan penelitian deskriptif eksploratif. Subjek penelitian adalah siswa Kelas XII SMK Jurusan Akuntansi di Sleman. Objek penelitian berupa respons jawaban tes sebanyak 300. Teknik pengumpulan data menggunakan tes dengan instrumen penelitian berupa soal tes sebanyak 40 butir. Teknik analisis data untuk melihat karakteristik kualitatif dilakukan dengan telaah butir oleh expert judgement sedangkan karakteristik soal kuantitatif menggunakan pendekatan Teori Tes Klasik dan Teori Respons Butir Model 1 Parameter Logistik. Analisis butir soal dilakukan menggunakan program QUEST. Hasil penelitian menunjukkan bahwa: (1) karakteristik soal kualitatif secara umum tergolong baik. Pada aspek materi terdapat $92,5 \%$ soal yang baik, aspek konstruksi dan bahasa $100 \%$ soal baik. (2) karakteristik soal kuantitatif berdasarkan pendekatan teori tes klasik memiliki tingkat kesukaran kategori sangat mudah $=7,5 \%$, mudah $=25 \%$, sedang $=67,5 \%$ sukar dan sangat sukar $=0 \%$. (3) karakteristik soal kuantitatif berdasarkan pendekatan teori respons butir memiliki tingkat kesukaran kategori sangat mudah $=7,5 \%$, mudah $=15 \%$, sedang $=60 \%$, sukar $=17,5 \%$ dan sangat sukar $=0 \%$.
\end{abstract}

Kata Kunci: karakteristik butir soal, akuntansi, teori tes klasik, teori respons butir.

\section{Abstract}

This study aims to determine the characteristics of the Try Out Vocational Accounting Theory Test items. Characteristics of the items seen include qualitative characteristics of items that include aspects of material, construction, language and the characteristics of quantitative questions about the level of difficulty. This research is a descriptive exploratory study. The subject of this study is Class XII students of the Vocational School of Accounting in Sleman. 
The object of this study is the response of 300 test answers. Data collection techniques using a test with a research instrument in the form of a test item as many as 40 items. Data analysis techniques to look at the characteristics of the questions qualitatively carried out by the review of items by expert judgment. Analysis of test items to determine the characteristics of the questions quantitatively using the approach of Classical Test Theory and Item Response Theory Model 1 Logistics Parameters. Item analysis was performed using the QUEST program. The results showed that: (1) the characteristics of qualitative questions were generally classified as good, where in the material aspect there were $92.5 \%$ good questions, construction aspects and $100 \%$ good questions. (2) the quantitative characteristics of the questions based on the classical test theory approach has a very easy category of difficulty $=7.5 \%$, easy $=25 \%$, moderate $=$ $67.5 \%$ difficult and very difficult $=0 \%$. (3) the characteristics of the questions quantitatively based on the theoretical response model of the model 1 Logistics Parameter has a very easy category of difficulty $=7.5 \%$, easy $=15 \%$, moderate $=60 \%$, difficult $=17.5 \%$ and very difficult $=0 \%$.

Keywords: item characteristics, accounting, classical test theory, item response theory.

\section{PENDAHULUAN}

Kegiatan penilaian dan evaluasi hasil belajar peserta didik merupakan salah satu hal yang penting dilakukan oleh pendidik ataupun instansi pendidikan. Penilaian dan evaluasi hasil belajar merupakan salah satu upaya yang dilakukan untuk memantau pencapaian kompetensi siswa setelah dilaksanakan proses pembelajaran. Berdasarkan Undang-Undang Nomor 20 Tahun 2003 mengenai Standar Nasional Pendidikan 57 ayat 1, evaluasi dilakukan dalam rangka pengendalian mutu pendidikan nasional sebagai bentuk akuntabilitas penyelengara pendidikan kepada pihak-pihak yang berkepentingan, di antaranya terhadap peserta didik, lembaga, dan program pendidikan. Salah satu evaluasi yang dilakukan pemerintah terhadap pelaksanaan pendidikan adalah dengan menyelenggarakan Ujian Nasional.

Ujian Nasional (UN) diselenggarakan oleh pemerintah setiap satu tahun satu kali secara serentak di seluruh Indonesia. Dalam Peraturan Menteri Pendidikan No. 20 tahun 2007 tentang standar penilaian dijelaskan bahwa Ujian Nasional (UN) adalah kegiatan pengukuran pencapaian kompetensi peserta didik pada beberapa mata pelajaran tertentu dalam kelompok mata pelajaran ilmu pengetahuan dan teknologi dalam rangka menilai pencapaian Standar Nasional Pendidikan. Hasil dari Ujian Nasional kemudian digunakan oleh pemerintah untuk membuat kebijakan khususnya dalam bidang pendidikan. Berdasarkan Peraturan Pemerintah Nomor 19 Tahun 2005 tentang Standar Nasional Pendidikan pada pasal 68 disebutkan bahwa hasil dari ujian nasional digunakan sebagai salah satu pertimbangan untuk pemetaan mutu program dan/atau satuan pendidikan. Pemetaan tersebut bertujuan untuk melihat kualitas pendidikan tiap-tiap daerah di seluruh Indonesia.

Penilaian kompetensi peserta didik melalui Ujian Nasional (UN)menggunakan instrumen tes. Menurut Djemari Mardapi (2012: 108), tes merupakan salah satu bentuk instrumen yang digunakan untuk melakukan pengukuran. Tujuan melakukan tes adalah untuk mengetahui pencapaian belajar atau kompetensi yang telah dicapai peserta didik untuk bidang tertentu.

Sebelum dilaksanakan Ujian Nasional, Dinas Pendidikan tingkat Provinsi maupun Kabupaten selalu menyelenggarakan uji coba dalam menghadapi Ujian Nasional yang biasa disebut dengan istilah try out. Tujuan dilaksanakannya try out adalah untuk meningkatkan mutu kualitas lulusan siswa. Hal ini dilaksanakan untuk melihat ketercapaian kompetensi siswa dalam pelaksanaan Ujian Nasional nanti, serta sebagai langkah validasi data dan mempersiapkan siswa dalam menghadapi Ujian Nasional. Pentingnya pelaksanaan try out 
dalam menghadapi Ujian Nasional tersebut menuntut Dinas Pendidikan sebagai penyelenggara mempersiapkan try out dengan baik.

Perencanaan try out dilaksanakan dengan beberapa tahap. salah satu tahap perencanaan try out yang paling penting adalah tahap penyusunan soal. Penyelenggaraan try out tersebut membutuhkan instrumen tes yang memiliki kualitas yang baik. Apabila instrumen tes yang digunakan dalam try out merupakan soal dengan kualitas yang baik, maka hasil dari try out tersebut dapat menunjukkan pencapaian kompetensi siswa yang sebenarnya, dan dapat digunakan untuk menganalisis kompetensi yang belum dicapai siswa dalam rangka menghadapi Ujian Nasional.

Suatu perangkat tes yang baik tersusun atas butir-butir yang baik (Retnawati, 2014, p.62). Untuk mengetahui kualitas atau mutu perangkat tes, maka perlu dilakukan analisis terhadap butir soal yang terdapat dalam perangkat tes. Melalui analisis yang dilakukan, maka dapat diketahui mutu atau kualitas perangkat tes serta kekurangan-kekurangan perangkat tes tersebut. Analisis butir dapat mengetahui tingkat kesukaran butir soal, daya pembeda dan juga efektivitas pengecoh (Mardapi, 2012, p.128). Selain itu, validitas dan reliabilitas instrumen tes juga akan diketahui.

Melalui analisis yang dilakukan, maka dapat diketahui mutu atau kualitas perangkat tes serta kekurangan-kekurangan perangkat tes tersebut. Menurut Djemari Mardapi (2012: p.128) analisis butir dapat mengetahui tingkat kesukaran butir soal, daya pembeda dan juga efektivitas pengecoh. Selain itu, validitas dan reliabilitas instrumen tes juga akan diketahui. Soal yang memiliki kualitas yang baik maka akan mampu menunjukkan kemampuan peserta tes yang sebenarnya.

Terdapat dua jenis analisis butir soal, yaitu analisis secara kualitatif atau teoritis dan analisis kuantitatif atau empiris. Analisis secara kualitatif sering disebut dengan telaah butir soal. Badrun Kartowagiran (2011) telaah soal atau analisis kualitatif adalah mengkaji secara teoritik soal tes yang telah tersusun. Telaah dilakukan pada butir soal dengan cara mencermati butir soal yang telah disusun dan dibandingkan apakah soal yang dibuat sudah sesuai dengan kompetensi dasar dan indikator yang telah ditentukan atau belum. Analisis kualitatif dilakukan mencakup analisis terhadap materi, kunstruksi dan bahasa. Analisis secara kuantitaif atau empiris adalah analisis yang dilakukan terhadap butir-butir soal untuk mengetahui informasi mengenai reliabilitas, tingkat kesukaran, daya beda serta keberfungsian distraktor/pengecoh.

Neșe Güler, et al (2014) menjelaskan bahwa ada dua teori utama yang digunakan untuk melihat kualitas soal, yaitu teori tes klasik (Classical Test theory) dan teori respons butir (Item Response Theory). Teori tes klasik merupakan pendekatan yang sangat sederhana dan mudah untuk dipahami dalam kegiatan analisis soal secara empiris. Secara tradisional, kemampuan masing-masing peserta ujian dilaporkan dalam hal jumlah item yang dijawab dengan benar. Ini merupakan keterbatasan atau kelemahan analisis soal dengan pendekatan teori tes klasik, di mana siswa dengan jumlah item yang sama menjawab dengan benar mungkin memiliki pola respons yang berbeda (yaitu, jawaban yang benar pada item yang berbeda) dan, dengan demikian, mungkin tidak memiliki tingkat kemahiran yang sama diukur oleh tes (Cappelleri, Lundy \& Hays, 2014).

Salah satu hal yang mempengaruhi hasil dari Ujian Nasional bisa disebabkan perangkat tes yang digunakan pada saat try out merupakan instrumen dengan kualitas yang kurang baik, sehingga dapat menyebabkan kesalahan dalam pengukuran. Oleh karena itu, soal yang digunakan untuk uji coba Ujian Nasional (try out) harus melalui tahap analisis soal baik secara kualiatatif dan kuantitatif. Termasuk soal try out yang digunakan untuk Sekolah Menengah Kejuruan (SMK).

Tujuan dari penelitian ini adalah mendeskripsikan kualitas soal Try Out Teori Kejuruan Akuntansi Buatan MGMP Kabupaten Sleman tahun secara kualitatif dan kuantitatif menurut 
pendekatan Teori Tes Klasik dan Teori Respons Butir. Karakteristik soal menurut Teori Tes Klasik dibatasi ada tingkat kesukaran soal, karena akan dibandingkan dengan hasil analisis kualitas soal berdasarkan Teori Respons Butir. Pada pendekatan Teori Respons Butir menggunakan model 1 Parameter Logistik yaitu meilihat kualitas soal berdasarkan tingkat kesukaran. Penelitian ini juga akan mendeskripsikan validitas isi dan reliabilitas soal.

Menurut Djemari Mardapi (2012: 128), tingkat kesukaran dalam teori tes klasik merupakan proporsi yang menjawab benar. Allen dan Yen (1979 : 122) menyatakan bahwa secara umum indeks kesukaran suatu butir sebaiknya terletak pada interval $0,3-0,7$. Indeks kesukaran dapat diklasifikasikan sebagai berikut:

\begin{tabular}{cc} 
Tabel 1. Kriteria Tingkat Kesukaran pada Teori Tes Klasik \\
\hline Range Tingkat Kesukaran & Keterangan \\
\hline TK $<\mathbf{0 , 3 0}$ & Sukar \\
\hline $\mathbf{0 , 3 0} \leq \mathbf{T K}<\mathbf{0 , 7 0}$ & Sedang \\
\hline TK $\geq \mathbf{0 , 7 0}$ & Mudah \\
\hline
\end{tabular}

Karakteristik soal berdasarkan pendekatan teori respons butir dengan model 1 Parameter Logistik didasarkan pada parameter tingkat kesukaran. Tingkat kesukaran soal berdasarkan pendekatan teori respons butir dikatakan baik apabila tingkat kesukaran soal berada pada logit -2 sampai +2 (DeMars, 2010, 21; Hambleton, 1991: 5). Selanjutnya Sumintono (2015: 81), menyatakan bahwa tingkat kesukaran suatu item soal dapat dapat dibagi menjadi kategori sulit, sedang, dan mudah. Tingkat kesukaran termasuk dalam kategori mudah jika indeks kesukarannya mendekati -2.00 , sedang jika indeks kesukarannya antara -1.00 dan +1.00 , dan sulit jika indeks kesukarannya mendekati +2.00 .

Selain dilihat dari karakteristik butir, soal yang baik harus memiliki validitas isi yang baik. Validitas isi tes dapat dihitung menggunakan formula aiken. Pada penelitian ini digunakan 5 orang guru akuntansi yang sudah memiliki pengalaman mengajar lebih dari 5 tahun. Aiken (1985) membagi kriteria validitas isi yang baik berdasarkan banyaknya rater dan kategori penskoran. Soal yang memiliki indeks validitas yang baik dengan menggunakan 5 rater dan 4 katagori penskoran sesuai dengan penelitian ini apabila indeks validitasnya minimal 0,87. Validitas isi instrumen ditentukan dengan menggunakan formula aiken, yaitu:

keterangan:

$$
V=\sum_{i=1}^{c-1} \frac{i n_{i}}{N(c-1)}
$$

$\mathrm{V}$ : indeks validitas isi dari

ni : banyaknya penilai (raters) yang memilih kriteria i

c :banyaknya kategori/ ke i

$\mathrm{N}$ : jumlah seluruh penilai

Indeks reliabilitas adalah ukuran konsistensi suatu skor tes dari satu pengukuran ke pengukuran lainnya. Reliabilitas juga menggambarkan konsistensi skor yang diperoleh oleh peserta tes yang sama ketika diberikan tes yang sama pada waktu yang berbeda. Menurut Saifudin Azwar (2015: 98) suatu instrumen tes dikatakan memiliki indeks reliabilitas yang baik apabila nilai indeks reliabilitas minimalnya sebesar 0,7 . Indeks reliabilitas soal pada penelitian ini dilihat berdasarkan hasil output pada analisis program QUEST.

Terdapat beberapa penelitian sebelumnya yang menganalisis karakteristik butir soal, diantaranya penelitian yang dilakukan oleh Amalia \& Widayati (2012) dan Wibawa (2019) 
yang menganalisis soal dengan pendekatan teori tes klasik. Bedanya dengan penelitian ini adalah analisis soal pada penelitian ini dilakukan dengan kualitatif dan kuantitatif. Pada analisis kualitatif, analisis meliputi aspek isi, konstruksi dan bahasa pada soal dilakukan oleh export judgement yaitu dosen akuntansi dan guru akuntansi SMK. Analisis soal secara kuantitatif dilakukan dengan pendekatan teori tes klasik dan teori respons butir model 3 Parameter Logistik. Selain itu penelitian ini juga menjelaskan validitas isi hasil penilaian export judgement dan juga reliabilitasnya.

\section{METODE PENELITIAN}

Penelitian ini termasuk jenis penelitian deskriptif eksploratif kuantitaif untuk melihat karakteristik perangkat tes try out teori kejuruan akuntansi SMK buatan MGMP di Kabupaten Sleman. Penelitian ini dilaksanakan di SMK se-Kabupaten Sleman, Provinsi Daerah Istimewa Yogyakartai. Subjek penelitian ini adalah siswa kelas XII SMK Kabupaten Sleman yang mengikuti tes try out teori kejuruan akuntansi sebanyak 300 siswa. Objek penelitian ini adalah perangkat tes dan respon siswa berupa lembar jawaban pada ujian try out teori kejuruan akuntansi yang berasal dari 6 SMK sebagai sampel berdasarkan teknik Stratified Random Sampling yaitu dipilih berdasarkan ranking hasil Ujian Nasional mata pelajaran teori kejuruan akuntansi. Ranking dipilih kembali berdasarkan nilai tertinggi, sedang dan terendah. Sekolah yang menjadi objek penelitian adalah SMK N 1 Godean, SMK N 1 Depok, SMK N 1 Tempel, SMK YPKK 2 Sleman, SMK Yapemda Sleman, SMK YPKK 3 Sleman, SMK Muhammadiyah 1 Turi, SMK Muhammadiyah 2 Moyudan, SMK Ma'arif 1 Sleman.

Teknik pengumpulan data yang digunakan dalam penelitian ini adalah dokumentasi. Data dalam penelitian ini dikumpulkan dengan menggunakan lembar telaah untuk expert judgement yang digunakan untuk melihat karakteristik soal secara kualitatif, dan respon jawaban try out untuk analisis kuantitatif (empiris).

Pendekatan kualitatif berupa analisis data melalui penelaahan butir-butir soal. Telaah butir soal dilakukan dari aspek materi atau isi, aspek konstruksi, dan aspek

bahasa untuk mengetahui karakteristik soal secara kualitatif. Telaah dilakukan oleh expert judgment dalam bidang akuntansi.

Selanjutnya perangkat tes dianalisis secara kuantitatif berdasarkan pendekatan teori tes klasik. Analisis soal dilakukan dengan bantuan program QUEST kemudian dilihat indeks tingkat kesukaran, daya pembeda serta reliabilitas soal. Berdasarkan hasil analisis butir soal tersebut, kualitas butir soal secara empiris dikategorikan baik atau tidak baik.

\section{HASIL PENELITAN DAN PEMBAHASAN}

\section{Validitas dan Raliabilitas Soal}

Validitas isi soal Try Out Teori Kejuruan Akuntansi buatan MGMP Sleman berdasarkan perhitungan dengan formula aiken cukup baik. Pada soal ini terdapat 27 soal yang memiliki indeks validitas isi minimal 0,87 dan termasuk katagori yang baik. Jumlah soal yang memiliki indeks validitas isi yang kurang baik sebanyak 13 soal, yaitu kurang dari 0,87 . Berikut ini dijelaskan sebaran butir soal yang memiliki validitas isi baik dan tidak baik pada Tabel 2 .

Tabel 2. Validitas Isi Butir Soal Akuntansi Berdasarkan Formula Aiken

\begin{tabular}{cccc}
\hline Validitas Isi & Nomor Soal & Jumlah & Persentase \\
\hline Baik & $4,5,9,10,11,13,14,16,17$, & 27 & $67,5 \%$ \\
& $18,19,24,25,26,27,28,29$, & & \\
& $30,31,32,34,35,36,37,38$, & & \\
& 39,40 & & \\
\hline
\end{tabular}




\begin{tabular}{cccc}
\hline Validitas Isi & Nomor Soal & Jumlah & Persentase \\
\hline Tidak Baik & $1,2,3,6,7,8,12,15,20,21$, & 13 & $32,5 \%$ \\
& $22,23,33$ & &
\end{tabular}

Soal Try Out Teori Kejuruan Akuntansi buatan MGMP Sleman ini memiliki indeks reliabilitas sebesar 0,98. Dapat dikatakan bahwa soal ini memiliki indeks reliabilitas yang cukup baik. Heri Retnawati (2016,: 84) menyatakan bahwa koefisien reliabilitas dapat diartikan sebagai koefisien keajegan atau kestabilan hasil pengukuran. Artinya soal Try Out Teori Kejuruan Akuntansi buatan MGMP Kabupaten Sleman ini dengan indeks reliabilitas 0,98 ini memiliki kestabilan hasil pengukuran.

\section{Kualitas Soal Try Out Teori Kejuruan Akuntansi secara Kualitatif}

Untuk mengetahui bagaimana kualitas soal try out akuntansi secara kualitatif, dilakukan melalui telaah butir soal yang dilakukan oleh expert judgment. Expert judgement dalam hal ini terdiri dari satu dosen akuntansi dan dua guru akuntansi SMK yang sudah memiliki pengalaman mengajar lebih dari 10 tahun. Telaah kulitatif dilihat berdasarkan kesesuaian soal pada aspek materi, konstruksi dan Bahasa. Hasil telaah soal ditampilkan pada Tabel 3.

Tabel 3. Hasil Telaah Butir Soal Try Out

\begin{tabular}{ccccccc}
\hline \multirow{2}{*}{ Aspek } & \multicolumn{7}{c}{ Kategori Soal } \\
& Baik & $\%$ & Kurang Baik & \% & Tidak Baik & \% \\
\hline Materi & 37 & 92,5 & 3 & 7,5 & 0 & 0 \\
\hline Konstruksi & 40 & 0 & 0 & 0 & 0 & 0 \\
\hline Bahasa & 40 & 0 & 0 & 0 & 0 & 0 \\
\hline
\end{tabular}

Berdasarkan hasil telaah kualitatif pada Tabel 3, diketahui bahwa pada aspek materi terdapat 37 soal yang termasuk katagori baik, dan 3 soal termasuk katagori kurang baik. Soal yang tidak baik merupakan hasil analisis dari pendapat expert judgement. Hal ini disebabkan karena soal yang disusun tidak sesuai dengan kisi-kisi soal.

\section{Kualitas Butir Soal Try Out Teori Kejuran Akuntansi Secara Kuantitatif Berdasarkan Teori Tes Klasik}

Setelah dilakukan analisis secara kualitatif melalui telaah terhadap butir soal yang dilakukan expert judgement, kemudian dilakukan analisis butir soal secara kuantitatif untuk mengetahui karakteristik soal secara kuantitatif. Analisis kuantitatif soal try out ini dilakukan dengan pendekatan teori tes klasik dengan program QUEST untuk melihat tingkat kesukaran butir soal. Tingkat kesukaran butir soal dalam teori tes klasik dapat diartikan sebagai persentase peserta tes yang menjawab butir soal tes tertentu dengan benar. Indeks tingkat kesukaran butir soal yang baik antara 0,30 sampai dengan 0,70 .

Tabel 3. Ringkasan Hasil Analisis Indeks Tingkat Kesukaran Butir Soal Berdasarkan Pendekatan Teori Tes Klasik

\begin{tabular}{ccccc}
\hline $\begin{array}{c}\text { Tingkat } \\
\text { Kesukaran }\end{array}$ & Kategori Soal & Nomor Butir & Persentase & Keputusan \\
\hline $\begin{array}{c}\text { Lebih dari } \\
0,90\end{array}$ & Sangat Mudah & $1,2,6$ & $7,5 \%$ & Ditolak \\
\hline $0,71-0,90$ & Mudah & $3,711,12,22,28,32,37$, & $25 \%$ & Direvisi \\
& & 38,39 & \\
\hline
\end{tabular}




\begin{tabular}{ccccc}
\hline $\begin{array}{c}\text { Tingkat } \\
\text { Kesukaran }\end{array}$ & Kategori Soal & Nomor Butir & Persentase & Keputusan \\
\hline $0,30-0,70$ & Sedang & $4,5,8,9,10,13,14,15,16$, & $67,5 \%$ & Diterima \\
& & $17,18,19,20,21,23,24$, & & \\
& $25,26,27,29,30,31,33$, & & \\
& & $34,35,36,40$ & \\
\hline $0,71-0,90$ & Sukar & - & $0 \%$ & Direvisi \\
\hline $0,90-1,00$ & Sangat Sukar & - & $0 \%$ & Ditolak \\
\hline
\end{tabular}

Berdasarkan Tabel 3 dapat dilihat hasil analisis soal pendekatan teori tes klasik pada program QUEST. Ditinjau dari tingkat kesukarannya soal try out teori kejuruan akuntansi buatan MGMP Kabupaten Sleman terdiri dari 3 soal (7,5\%) yang termasuk dalam kategori sangat mudah, 10 soal $(25 \%)$ yang termasuk katagori mudah dan 27 soal $(67,5 \%)$ termasuk dalam kategori sedang. Tidak ada soal yang termasuk dalam kategori sukar dan sangat sukar.

Tingkat kesukaran yang diterima dari hasil analisis dengan menggunakan teori tes klasik ini adalah antara 0,3 sampai dengan 0,7. Artinya soal memiliki tingkat kesukaran kategori sedang. Hasil penelitian ini mendukung penelitian yang dilakukan oleh Wibawa (2019) dimana soal yang diterima dan termasuk kategori baik adalah soal yang memiliki indeks tingkat kesukaran antara 0,3 sampai dengan 0,7 .

\section{Kualitas Butir Soal Try Out Teori Kejuran Akuntansi Secara Kuantitatif Berdasarkan Teori Respons Butir}

Analisis kuantitatif menggunakan pendekatan teori respons butir sedikit berbeda dengan pendekatan teori tes klasik. Pada analisis dengan pendekatan teori respons butir terlebih dahulu dilakukan uji asumsi. Uji asumsi terdiri dari uji unidimensi, independensi local dan invariasi parameter.

\section{$\underline{\text { Uji Asumsi Unidimensi }}$}

Uji asumsi unidimensi ini dilakukan untuk mengetahui apakah perangkat tes try out teori kejuruan akuntansi ini mengukur satu kemampuan (trait) atau tidak, yaitu mengukur kemampuan siswa SMK di Kabupaten Sleman pada mata pelajaran produktif akuntansi yang nantinya akan digunakan untuk pemetaan kemampuan dalam menghadapi Ujian Nasional. Uji unidimensi tes ini dilakukan dengan analisis faktor menggunakan program SPSS 20.

Hasil analisis dengan menggunakan analisis faktor menunjukkan bahwa hasil analisis faktor terdapat 11 nilai eigen yang lebih dari 1, sehingga dikatakan bahwa 40 item soal tersebut membentuk 11 faktor yang menjelaskan sekitar 55,063\% dari total varians. Hasil tersebut juga menunjukkan bahwa faktor yang paling dominan terletak pada faktor 1 dengan nilai eigen sebesar 9,439 dimana nilainya lebih dari lima kali nilai eigen pada faktor kedua, sehingga dapat dikatakan bahwa perangkat tes try out teori kejuruan akuntansi paket A bersifat unidimensi. Berdasarkan nilai eigen yang diperoleh, dapat pula disajikan dengan scree plot sebagai berikut: 


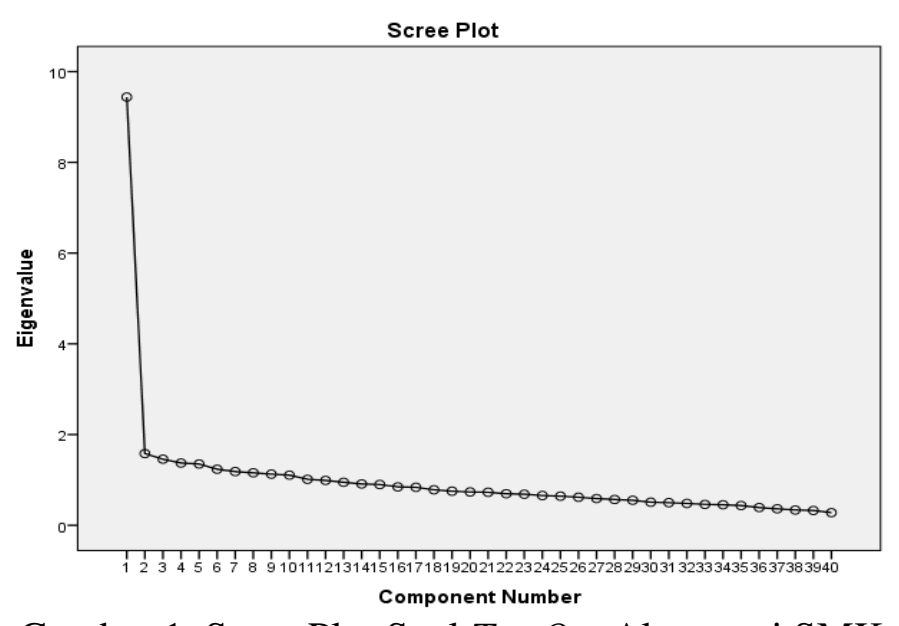

Gambar 1. Scree Plot Soal Try Out Akuntansi SMK

Gambar 1 merupakan scree plot hasil uji asumsi unidimensi. Dapat dilihat bahwa factor 1 memiliki nilai sebesar 9,439, disusul dengan factor 2 dengan nilai 1,782 dan factor-faktor lain tang berada di bawahnya. Hal ini dapat diartikan bahwa faktor 1 sangat dominan terhadap faktor-faktor lain. Dengan demikian asumsi unidimensi dipenuhi. Hasil penelitian ini sesuai dengan asumsi pada pendekatan teori respons butir dimana satu set soal atau tes hanya memiliki satu sifat laten. Hasil ini menyiratkan bahwa kinerja masing-masing peserta ujian diasumsikan diatur oleh faktor tunggal, yang disebut sebagai kemampuan (Eleje, L., I \& Onah, F., E, 2018).

\section{Uji Asumsi Independensi Lokal}

Independensi lokal mengacu pada probabilitas sukses peserta tes pada butir tertentu hanya tergantung pada parameter butir yang bersangkutan serta pada abilitas peserta tes $(\theta)$ (Hasmy, Suryanto \& Kumaidi, 2013). Ini menyiratkan bahwa kemungkinan peserta ujian menjawab item dengan benar tidak terpengaruh oleh jawaban yang diberikan kepada item lain dalam tes.

Uji asumsi independensi lokal untuk paket A dibuktikan dengan matriks varianskovarians dari kemampuan siswa yang mengerjakan soal paket A. Hasil yang diperoleh menunjukkan bahwa menunjukkan bahwa nilai elemen diluar diagonal mendekati 0 , artinya bahwa perangkat tes ujian semester kimia memenuhi uji asumsi indepedensi lokal. Hasil penelitian ini sesuai dengan pendapat yang dikemukakan oleh Ojerinde (2013), bahwa Independensi lokal tidak berarti bahwa item tidak saling berkorelasi, tetapi kinerja pada item yang berbeda adalah independen tetapi tergantung pada kemampuan siswa. Dengan demikian, probabilitas bahwa seorang siswa akan menjawab dengan benar setiap dua item harus merupakan produk dari probabilitas bahwa siswa akan menjawab dengan benar setiap item yang terpisah. Juga, hubungan antara dua item tidak boleh berbeda secara signifikan dari nol, jika tidak, dapat dikatakan bahwa respon terhadap item dipengaruhi oleh faktor-faktor asing lainnya selain apa yang dirancang untuk diukur oleh instrumen (Ojerinde, 2013).

\section{Uji Asumsi Invariansi Parameter}

Uji asumsi invariansi parameter terdiri dari dua jenis. Pertama adalah uji invariansi parameter butir/item soal. Uji invariansi parameter butir/item ini bertujuan untuk mengetahui apakah karakteristik item pada perangkat tes tidak berubah meskipun dijawab oleh kelompok siswa yang berbeda. Kedua adalah uji invariansi parameter kemampuan peserta tes. Tujuannya adalah untuk melihat apakah estimasi kemampuan siswa tidak berubah meskipun item soal yang dijawab berubah-ubah. Pengujian dilakukan dengan menggunakan diagram pencar (scree plot) yaitu sebagai berikut. 


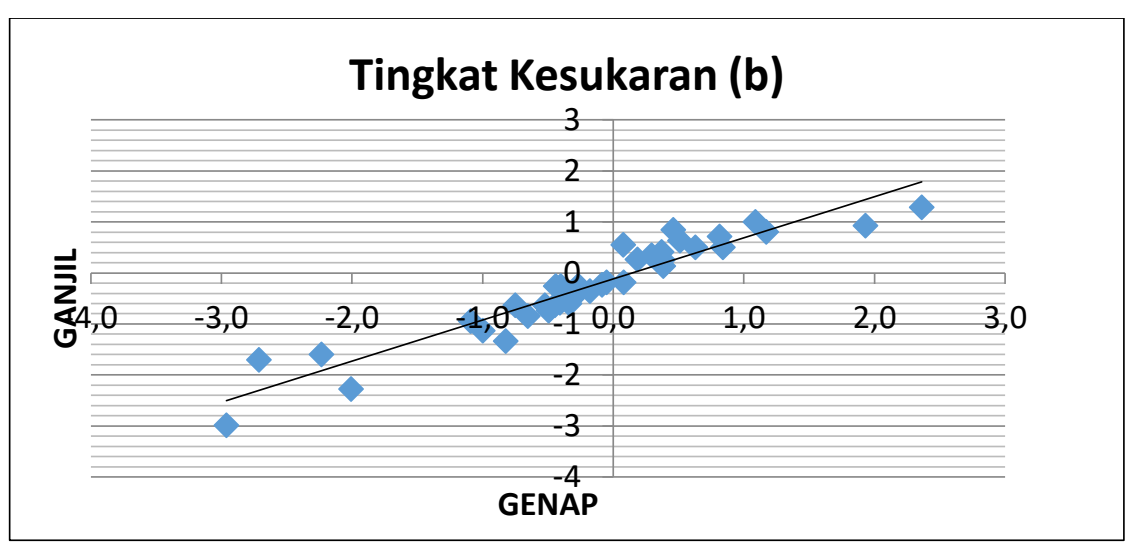

Gambar 2. Diagram Pencar Invariansi Parameter Tingkat Kesukaran

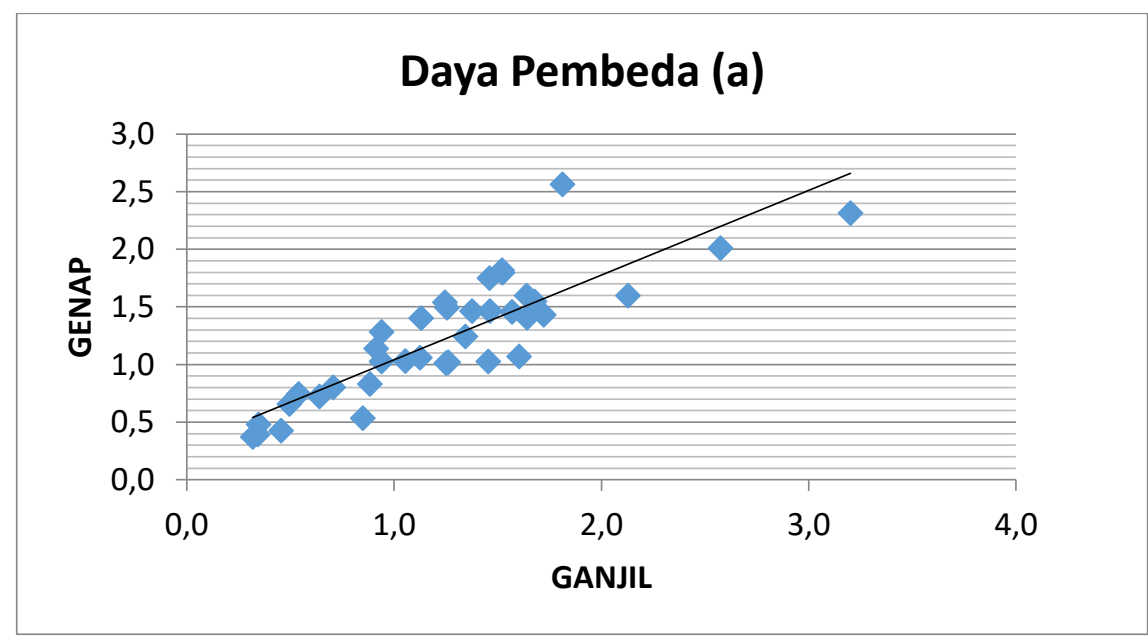

Gambar 3. Diagram Pencar Invariansi Parameter Daya Pembeda

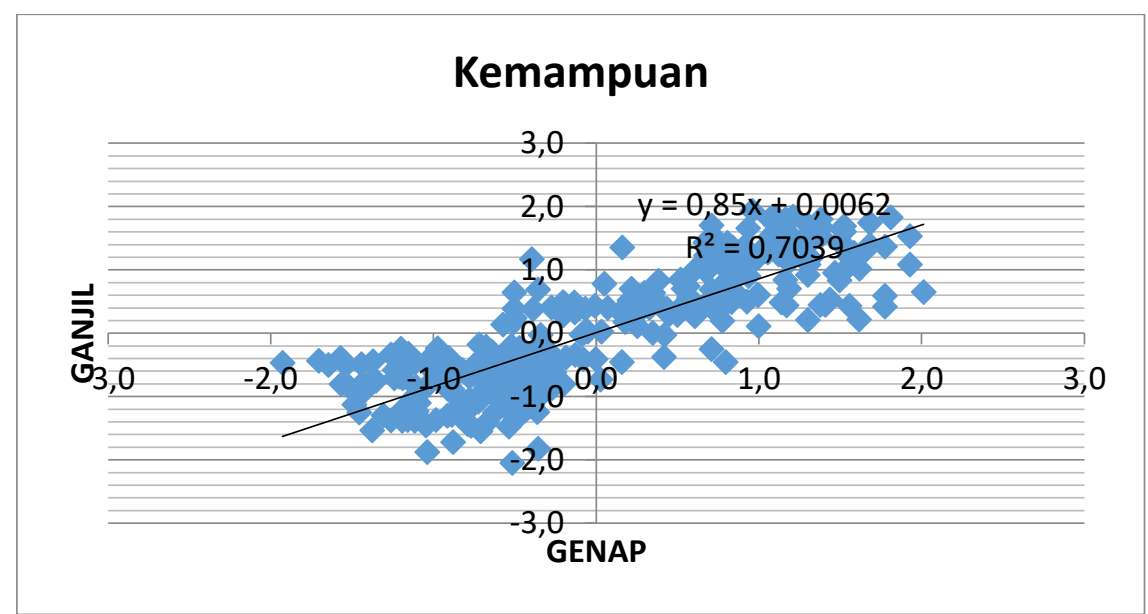

Gambar 4. Diagram Pencar Invariansi Parameter Kemampuan Peserta

Berdasarkan Gambar 3, 4 dan 5 dapat dilihat bahwa secara keseluruan masing-masing titik berada relatif dekat dengan garis diagonal. Dapat diartikan bahwa invariansi parameter soal paket A terpenuhi. Setelah uji asumsi terpenuhi, kualitas soal berdasarkan pendeketan teori respons butir dapat dilihat berdasakan hasil analisis pada tingkat kesukaran soal. Hasil analisis dengan pendekatan teori respons butir 1 parameter logistik ditampilkan pada Tabel 4. 
Tabel 4. Ringkasan Hasil Analisis Indeks Tingkat Kesukaran Butir Soal Berdasarkan Pendekatan Teori Respons Butir

\begin{tabular}{ccccc}
\hline $\begin{array}{c}\text { Tingkat } \\
\text { Kesukaran }\end{array}$ & Kategori Soal & Nomor Butir & Persentase & Keputusan \\
\hline $\begin{array}{c}\text { Kurang } \\
\text { dari }-2,00\end{array}$ & Sangat Mudah & $1,2,6$ & $7,5 \%$ & Ditolak \\
\hline $\begin{array}{c}-2,00 \mathrm{~s} / \mathrm{d}- \\
0,99\end{array}$ & Mudah & $3,7,11,22,32,38$ & $15 \%$ & Direvisi \\
\hline $\begin{array}{c}-1,00 \mathrm{~s} / \mathrm{d} \\
+1,00\end{array}$ & Sedang & $\begin{array}{l}4,8,9,10,12,13,14,15, \\
16,18,19,20,23,24,25,\end{array}$ & \\
& & $26,27,28,29,35,35,37$, & & Diterima \\
& & 39,40 & \\
\hline$+1,01 \mathrm{~s} / \mathrm{d}$ & Sukar & $5,17,21,30,31,33,34$ & $17,5 \%$ & Direvisi \\
$+2,00$ & & - & 0 & Ditolak \\
\hline $\begin{array}{c}\text { Lebih dari } \\
+2,00\end{array}$ & Sangat Sukar & & & \\
\hline
\end{tabular}

Berdasarkan Tabel 4 dapat dilihat hasil analisis soal pendekatan teori respons butir pada program QUEST. Ditinjau dari tingkat kesukarannya soal try out teori kejuruan akuntansi buatan MGMP Kabupaten Sleman terdiri dari 3 soal $(7,5 \%)$ yang termasuk dalam kategori sangat mudah, 6 soal $(15 \%)$ yang termasuk katagori mudah, 24 soal $(60 \%)$ termasuk dalam kategori sedang dan 7 soal $(17,5 \%)$ termasuk kategori sukar. Tidak ada soal yang termasuk dalam kategori sangat sukar.

Tingkat kesukaran yang diterima dari hasil analisis dengan menggunakan teori respons butir ini adalah antara $-2,00$ sampai dengan $+2,00$. Hasil penelitian ini mendukung penelitian yang dilakukan oleh Wibawa (2019) dimana soal yang diterima dan termasuk kategori baik adalah soal yang memiliki indeks tingkat kesukaran antara 0,3 sampai dengan 0,7 .

\section{SIMPULAN DAN SARAN}

Berdasarkan hasil penelitian dan pembahasan, dapat dirumuskan beberapa simpulan yaitu: (1) karakteristik soal kualitatif secara umum tergolong baik. Pada aspek materi terdapat $92,5 \%$ soal yang baik, aspek konstruksi dan bahasa $100 \%$ soal baik. (2) karakteristik soal kuantitatif berdasarkan pendekatan teori tes klasik memiliki tingkat kesukaran kategori sangat mudah $=7,5 \%$, mudah $=25 \%$, sedang $=67,5 \%$ sukar dan sangat sukar $=0 \%$. (3) karakteristik soal kuantitatif berdasarkan pendekatan teori respons butir memiliki tingkat kesukaran kategori sangat mudah $=7,5 \%$, mudah $=15 \%$, sedang $=60 \%$, sukar $=17,5 \%$ dan sangat sukar $=0 \%$. Berdasarkan simpulan penelitian, dapat dirumuskan beberapa saran yaitu: (1) butir soal yang memiliki aspek materi yang tidak baik, sebaiknya dilihat kembali kesesuaian antara soal dengan kisi-kisi soal yang telah dibuat sebelumnya. (2) butir soal yang memiliki karakteristik baik sebaiknya digunakan sebagai rintisan untuk pembuatan bank soal yang terstandar sehingga dapat bermanfaat bagi penilaian pembelajaran akuntansi SMK selanjutnya; (3) butir soal yang perlu direvisi diharapkan segera direvisi sesuai dengan letak kekurangan soal untuk memperbaiki kualitas butir soal, dan setelah soal tersebut baik dapat dimasukan dalam rintisan bank soal; (4) butir soal yang ditolak sebaiknya tidak diikutkan dalam soal tes selanjutnya, dan (5) penelitian ini menganalisis butir soal dengan pendekatan teori tes klasik dan teoris respons butir model 1 Parameter logistic, sehingga hanya meilihat karakteristik berdasarkan parameter tingkat kesukaran saja, sehingga disarankan untuk penelitian selanjutnya dengan tema yang sama dapat menggunakan pendekatan teori respons butir dengan model 2 Parameter Logistik 
atau 3 Parameter Logistik. (6) diperlukan pelatihan analisis butir soal bagi guru terutama yang tegabung dalam MGMP agar dapat mengetahui kuaitas soal yang dibuat.

\section{DAFTAR PUSTAKA}

Aiken. (1985). Three coefficient for analyzing the reliability and validity of ratings. Educational and Psycological Measurement, 45, 131-142.

Amalia, A.N. \& Widayati, A. (2012). Analisis Butir Soal Tes Kendali Mutu Kelas XII SMA Mata Pelajaran Ekonomi Akuntansi di Kota Yogyakarta Tahun 2012. Jurnal Pendidikan Akuntansi Indonesia, Vol. X, No. 1, 1-26.

Allen, M. J \& Yen, W. M. (1979). Introduction to measurement theory. Montery: Brooks: Cole Publishing Company.

Azwar, S. (2015). Reliabilitas dan validitas. Yogyakarta: Pustaka Pelajar.

Cappelleri, J.C., Lundy, J.J., \& Hays, R. D. (2014). Overview of classical test theory and item response theory for quantitative assessment of items in developing patientreported outcome measures. Doi: 10.1016/j.clinthera.2014.04.006

DeMars, C. (2010). Item response theory understanding statistics measurement. New York: Oxford University Press, Inc.,

Eleje, L., I \& Onah, F., E. (2018). Comparative Study of Classical Test Theory and Item Response Theory Using Diagnostic Quantitative Economics Skill Test Item Analysis Results. European Journal of Educational \& Social Sciences. 3(1), 71-89.

Hasmy, A., Suryanto \& Kumaidi. (2013) Robustness Model-Model Respons Butir terhadap Pelanggaran Asumsi Independensi Lokal Butir. Jurnal Penelitian dan Evaluasi Pendidikan, 2, 215-229.

Kartowagiran, Badrun. (Juli 2011). Penulisan butir soal. Makalah disajikan dalam Pelatihan Penulisan dan Analisis Butir Soal bagi Guru SMP Provinsi DIY, di Pascasarjana Universitas Negeri Yogyakarta.

Mardapi, Djemari. (2012). Pengukuran, penilaian \& evaluasi pendidikan. Yogyakarta: Nuha Medika.

Menteri. (2007). Peraturan Menteri Pendidikan No. 20 tahun 2007 tentang Standar Penilaian.

Neșe Güler, et al. (2014). Comparison of classical test theory and item response theory in terms of item parameters. Journal of Research on Education, 2, 1-6.

Ojerinde, D. (2013). Classical Test Theory (CTT) VS Item Response Theory (IRT): AN EVALUATION OF THE COMPARABILITY OF ITEM ANALYSIS RESULTS. Diakses dari https://pdfs.semanticscholar.org/aa27/637d699b7e26ee1 f7578d0fe2b8173ad769f.pdf?_ga=2.46379111.1559312837.1566266343142625523.1566266343 pada tanggal 20 Agustus 2019 Pukul 09.10 WIB

Presiden. (2005). Peraturan Pemerintah Nomor 19 Tahun 2005 tentang Standar Naisonal Pendidikan

Republik Indonesia. (2003). Undang-Undang Nomor 20 Tahun 2003 tentang Standar Nasional Pendidikan

Retnawati, H. (2014). Teori respons butir dan penerapannya. Yogyakarta: Nuha Medika

Retnawati, H. (2016). Validitas Reliabilitas dan Karakteristik Butir. Yogyakarta: Parama Publishing.

Sumintono, B. \& Widhiarso, W. (2015) Apliksi Pemodelan Rasch pada Assessment Pendidikan. Cimahi: Trim Komunikata

Wibawa, E. A. (2019). Karakteristik Butir Soal Tes Ujian Akhir Semester Hukum Bisnis. Jurnal Pendidikan Akuntansi Indonesia, Vol. XVII, No. 1, 87-96. 